\title{
IDENTIFIKASI AKTIVITAS EKSTRAK ETANOLIK BUAH MANGGA (Mangifera indica L.) PADA MENCIT JANTAN (Mus musculus) SEBAGAI PRODUK IMUNOGLOBULIN (IgM)
}

\author{
Herwin, Meilani \\ Fakultas Farmasi Universitas Muslim Indonesia, Makassar \\ Email : herwinfarmasi@gmail.com
}

\begin{abstract}
Mango fruit (Mangifera indica $L$ ) is a plant which grow in Indonesia and contain antioxidant as carotenoid (Vitamin A), vitamin $C$ and also various phenolic compound. The aim of the investigation was to find out the activity of ethanol extract of mango fruit on male guinea pig (Mus musculus) as an immunoglobulin product. The test of immunomodulator was using hemagglutination antibody titer. The extracts were in concentration of $2 \%, 4 \%, 6 \%, 8 \%$ and $10 \%$ administered orally 1 $\mathrm{mL} / 30 \mathrm{~g} \mathrm{BW}$ of the mouse which pre-immunized with $2 \% \mathrm{v} / \mathrm{v}$ red blood cells of the lamb. The results showed that the activity of the IgM in day seventh was raised in concentration extract $6 \%$ and $8 \%$ w/v while concentration extract $2 \%$ and $10 \%$ were the same to the control and the averages titer of immunoglobulin was $1 / 8$, on the other hand concentration of the extract $4 \%$ was low in IgM activity was 1/4.
\end{abstract}

Keywords: Ethanol Extract of Mango Fruit Activity (Mangifera indica L), Male Mouse (Mus musculus), Immunoglobulin (IgM).

\section{PENDAHULUAN}

Mangga (Mangifera indica L) merupakan tumbuhan yang banyak ditemukan di Indonesia. Rasa buah mangga yang manis-asam, bertekstur lunak, dan berwarna kuning-jingga temyata memiliki beragam manfaat. Dalam daging buah mnangga terkandung berbagai macam zat gizi yang bermanfaat bagi kesehatan. Kandungan antioksidan seperti karotenoid (vitamin A) dan vitamin C berperan dalam pencegahan penyakit kanker, Semeritara itu, kandungan kalium dan vitamin $\mathrm{C}$ berperan dalam permeliharaan kesehatan jantung. Senyawa fenol seperti asam ellagat, gelatonin, dan mangiferin yang terkandung dalam mangga dapat memberikan kontribusi bermanfaat terhadap kesehatan. Senyawa fenol ini dipercaya berguna untuk memperbaiki sel-sel yang teroksidasi oleh radikal bebas penyebab kanker dan penyakit degeneratif lainnya. Selain berperan sebagai antikanker, senyawa fenol 
Identifikasi Aktivitas Ekstrak Etanolik Buah Mangga (Mangifera indica L.) Pada mencit jantan (Mus musculus) Sebagai Produk Imunoglobulin (IgM)

seperti mangiferin dan asam ellagat berperan sebagai antiinflamasi yang dapat membantu meningkatkan sistem imunitas tubuh. ${ }^{1}$

Penelitian sebelumnya telah menunjukkan bahwa mangga memiliki aktivitas antioksidan dan antikanker dimana aktivitasnya diukur dengan memeriksa efek pada kinetika siklus sel dan kemampuan untuk menghambat induksi kimia transformasi neoplastik dari garis sel mamalia. Dari penelitian tersebut didapatkan bahwa seluruh jus mangga efektif dalam mengurangi jumlah perubahan foci dalam uji transformasi neoplastik secara tergantung dosis. ${ }^{2}$ Pada penelitian identifikasi aktivitas imunoglobulin $M$ (Ig.M) ekstrak etanolik daun ceplukan (physalis minima linn.) pada mencit didapatkan hasil bahwa ekstrak etanolik daun Ceplukan (Physalis minima Linn.) konsentrasi $4 \%$, $8 \%$ dan $12 \%$ b/v dapat meningkatkan aktivitas Ig.M dimana ceplukan mengandung asam klorogenat, asam citrun, fisalin, alkaloid dan polifenol. ${ }^{3}$

Berdasarkan hal tersebut, maka perlu dilakukan penelitian pengaruh ekstrak etanolik buah mangga pada mencit (Mus muscullus) jantan terhadap aktivitas Imunoglobulin $\mathrm{M}$ (IgM) sehingga dapat digunakan sebagai obat tradisional dalam bidang farmasi.

\section{METODE PENELITIAN}

\section{Tempat Dan Waktu Penelitian}

Penelitian dilakukan di Laboratorium Farmakologi Fakultas Farmasi Universitas Muslim Indonesia Makassar tahun 2016.

\section{Alat dan Bahan Penelitian}

Alat-alat yang digunakan adalah alat rotavapor, autoklaf, batang pengaduk, Erlenmeyer, labu alas bulat, mikropipet, piring Mikrotitrasi (Wheel plate) 96 lubang, sentrifuge, tabung venoject, timbangan analitik, timbangan gram, tip pipet, water bath.

Bahan-bahan yang digunakan adalah alumunium foil, Sel darah merah Domba, etanol, Mencit (Mus musculus), Kertas saring, $\mathrm{Na} \mathrm{CMC}$, larutan PBS, buah mangga (Mangifera indica $\mathrm{L}$ ).

\section{Prosedur Penelitian}

\section{Penyiapan Sampel}

Sampel yang digunakan yaitu mangga golek sebanyak 10 kgdiiris tipis dan dikeringkan dalam oven pada suhu $37-40^{\circ} \mathrm{C}$ selama $4-5$ jam kemudian dijemur sampai diperoleh berat konstan (kering). Buah mangga kering kemudian dihaluskan menjadi serbuk, hasil yang diperoleh digunakan sebagai sampel penelitian. 
Identifikasi Aktivitas Ekstrak Etanolik Buah Mangga (Mangifera indica L.) Pada mencit jantan (Mus musculus) Sebagai Produk Imunoglobulin (IgM)

Ekstraksi Buah Mangga

Daging buah mangga yang telah kering dihaluskan dengan blender. Kemudian dimaserasi dengan etanol $96 \%$ sampai semuanya terendam. Diaduk sekali sekali dan dibiarkan selama 5 hari kemudian disaring dan ampasnya dimaserasi lagi. Perlakuan ini dilakukan secara berulang sebanyak tiga kali yang masing-masingnya selama 5 hari. Semua filtrat disatukan, kemudian didestilasi vakum dan hasil destilat dikentalkan dengan menggunakan rotary evaporator hingga diperoleh ekstrak kental.

\section{Penyiapan Bahan}

\section{Pembuatan Phosphat Buffered Saline (PBS)}

Phospat Buffered Saline (PBS) disiapkan dengan terlebih membuat larutan $A$ yaitu larutan $\mathrm{KH}_{2} \mathrm{PO}_{4} \cdot \mathrm{H}_{2} \mathrm{O}$ $1,38 \mathrm{~g} / \mathrm{L}$ dan $\mathrm{KCl} 8,3 \mathrm{~g} / \mathrm{L}$ dan larutan $\mathrm{B}$ yaitu larutan $\mathrm{NaH}_{2} \mathrm{PO}_{4} \quad 1,42 \mathrm{~g} / \mathrm{L}$ dan $\mathrm{NaCl} 8,5 \mathrm{~g} / \mathrm{L}$. selanjutnya $280 \mathrm{~mL}$ larutan A ditambahkan pada $720 \mathrm{~mL}$ larutan B.

\section{Penyiapan Suspensi Sel Darah Merah (SDMD) $2 \%$}

Sebanyak $1 \mathrm{~mL}$ darah domba ditampung dalam tabung yang bersih dan telah dikeringkan yang berisi dengan $1 \mathrm{mg}$ EDTA yang berfungsi sebagai antikoagulan. Kemudian disentrifus pada kecepatan 1500 rpm untuk memisahkan sel darah merah domba (SDMD) dari plasmanya. Sel darah merah domba yang didapatkan dicuci dengan PBS dalam tabung, lalu tabung tersebut dibolak-balik beberapa kali, kemudian disentrifus kembali. Pencucian dilakukan paling sedikit 3 kali. Setelah disentrifus, PBS dipisahkan sehingga yang ter-tinggal adalah SDMD 100\%, lalu ditambahkan lagi PBS dengan jumlah yang sama hingga diperoleh suspensi SDMD $50 \%$, kemudian sebanyak $0,4 \mathrm{~mL}$ diencerkan dengan 9,6 $\mathrm{mL}$ PBS hingga diperoleh suspensi antigen dengan konsentrasi SDMD $2 \% \mathrm{v} / \mathrm{v}$.

\section{Pembuatan Suspensi Ekstrak Etanol Buah Mangga}

Ekstrak etanol buah mangga dibuat dengan menambahkan larutan koloidal Na-CMC 1\% b/v sebagai pembawa, dibuat dalam konsentrasi $2 \% \mathrm{~b} / \mathrm{v}, 4 \% \mathrm{~b} / \mathrm{v}$ dan $6 \% \mathrm{~b} / \mathrm{v}, 8 \%$ dan $10 \%$. Cara pembuatan konsentrasi $2 \%$ $\mathrm{b} / \mathrm{v}$ adalah dengan menimbang ekstrak sebanyak 2 gram kemudian digerus dalam lumpang, lalu ditambahkan larutan $\mathrm{Na}-\mathrm{CMC}$ 1\% b/v dalam labu terukur $100 \mathrm{~mL}$ hingga tanda. Untuk membuat suspensi ekstrak dengan konsentrasi $4 \%$ b/v, $6 \%$ b/v, $8 \%$ dan $10 \% \mathrm{~b} / \mathrm{v}$ dilakukan dengan cara yang sama dengan menimbang ekstrak 
Identifikasi Aktivitas Ekstrak Etanolik Buah Mangga (Mangifera indica L.) Pada mencit jantan (Mus musculus) Sebagai Produk Imunoglobulin (IgM)

masing-masing sebanyak 4 gram, 6 gram, 8 gram dan 10 gram. Suspensi dibuat segar setiap kali pertakuan.

Tahapan Perlakuan Hewan Coba Mencit Jantan (Mus musculus)

Perlakuan Hewan Coba Mencit Jantan.

Hewan uji yang digunakan adalah mencit jantan (Mus musculus) yang sehat dengan bobot badan 20 $30 \mathrm{~g}$, sebanyak 18 ekor dimana 1 kali perlakuan menggunakan 3 mencit yang akan diberi perlakuan. Perlakuan 1 adalah pemberian $\mathrm{NaCMC}$ sebagai kontrol, perlakuan 2 adalah pemberian ekstrak buah mangga2 \%, perlakuan 3 dengan ekstrak buah mangga $4 \%$, perlakuan 4 dengan ekstrak buah mangga $6 \%$, perlakuan 5 dengan ekstrak buah mangga 8\%, dan perlakuan 6 dengan ekstrak buah mangga $10 \%$.

\section{Imunisasi Hewan Coba Mencit Jantan Secara Intraperitonial}

Mula-mula mencit diimunisasi secara intraperitoneal dengan SDMD 2 \% sebanyak $1 \mathrm{~mL}$. Selanjutnya masing-masing diberi sediaan seperti di atas dengan volume $1 \mathrm{~mL}$ per 30 gram bobot badan secara oral setiap hari selama 5 hari untuk pengamatan terhadap IgM. Pada hari ke-6, darah mencit jantan diambil untuk mengetahui aktivitas IgM. Cuplikan darah dibiarkan membeku atau menggumpal pada suhu kamar selama 2 jam, lalu disentrifus dengan kecepatan 3000 rpm selama 10 menit dan diambil serumnya (supernatan).

\section{Pengujian Hewan Coba Mencit Jantan (Mus musculus) Secara Hemaglutinasi}

Serum yang diperoleh lalu diencerkan secara "double dilution" dengan PBS dengan perbandingan $1 / 4,1 / 8,1 / 16,1 / 32,1 / 64,1 / 128,1 / 256$, dan 1/512. Dari masing-masing perbandingan ini dipipet sebanyak 50 $\mu \mathrm{L}$ ke dalam 8 sumur piring mikrotiter (well plate 96) untuk setiap konsentrasieksrtak etanol buah mangga, setelah itu ditambah-kan $50 \mu \mathrm{L}$ suspensi sel darah merah domba $2 \%$ pada setiap sumur dan digoyanggoyang selama 5 menit agar homogen. Selanjutnya diinkubasi pada suhu $37^{\circ} \mathrm{C}$ selama 60 menit dan didiamkan 24 jam pada suhu kamar. Setelah itu, dilakukan pengamatan pengenceran tertinggi dari setiap serum darah mencit jantan yang masih dapat mengaglutinasi sel darah merah domba. Pengamatan secara hemaglutinasi, yaitu antibodidiinduksi dengan antigen dengan sel darah merah domba (SDMD), 24 jam setelah diinduksi dilakukan pemberian ekstrak selama 5 hari berturut-turut untuk 
Identifikasi Aktivitas Ekstrak Etanolik Buah Mangga (Mangifera indica L.) Pada mencit jantan (Mus musculus) Sebagai Produk Imunoglobulin (IgM)

pengamatan IgM. Efek sebagai imunomodulator diamati dari terjadinya aglutinasi pada serial pengenceran serum (mengandung antibodi) saat sel darah merah domba (SDMD) ditambahkan kembali dalam sumur mikrotiter.
HASIL PENELITIAN

Hasil Ekstraksi Buah Mangga (Mangifera indica) Dengan Metode Maserasi

Buah mangga yang telah dikeringkan sebanyak $500 \mathrm{~g}$ diekstraksi secara maserasi menggunakan cairan penyari diperoleh ekstrak etanol 85,055 g, terlihat pada tabel 1.

Tabel 1. Hasil Maserasi Buah mangga menggunakan etanol $96 \%$.

\begin{tabular}{clc}
\hline No. & \multicolumn{1}{c}{ Pengamatan } & Bobot Maserasi \\
\hline 1. & Berat Sampel & $500 \mathrm{~g}$ \\
2. & Jumlah cairan penyari & $6000 \mathrm{~mL}$ \\
3. & Jumlah ekstrak cair & $3050 \mathrm{~mL}$ \\
4. & Bobot ekstrak & $85,055 \mathrm{~g}$ \\
5. & Persentase ekstrak (\%) rendamen & $17,010 \%$ \\
\hline
\end{tabular}

$$
\begin{aligned}
\% \text { rendamen } & =\frac{\text { Bobot ekstrak }}{\text { Bobot sebelum diekstraksi }} \times 100 \%=\frac{85.055}{500.0131} \times 100 \% \\
& =17,010 \% .
\end{aligned}
$$

\section{Pengujian Hewan Coba Mencit Jantan (Mus musculus) Secara Hemaglutinasi}

Tabel 2. Profil Titer Imunoglobulin $M$ (IgM) pada sumur mikrotitrasi dengan interprestasi hasil berdasarkan hemaglutinasi setelah pemberian ekstrak etanol buah Mangga (Mangifera indica L)

\begin{tabular}{cccccccccccccccc}
\hline \multirow{2}{*}{ Pengenceran } & 1 & 2 & 3 & 17 & 18 & 7 & 8 & 9 & 10 & 11 & 13 & 14 & $\mathbf{N}$ & $\mathbf{N}$ & $\mathbf{N}$ \\
\cline { 2 - 28 } & & $2 \%$ & & $4 \%$ & & $6 \%$ & & $8 \%$ & & $10 \%$ & & Kontrol (-) \\
\hline $1 / 512$ & - & - & - & - & - & - & - & - & + & + & - & - & - & - & - \\
$1 / 128$ & - & - & - & - & - & - & - & - & + & + & - & - & - & - & - \\
$1 / 64$ & - & - & - & - & - & - & - & - & + & + & - & - & - & - & - \\
$1 / 32$ & - & - & - & - & - & + & - & - & + & + & - & - & - & - & - \\
$1 / 16$ & - & - & - & - & - & + & + & - & + & + & - & - & - & - & - \\
$1 / 8$ & + & + & + & - & - & + & + & + & + & + & + & + & + & + & + \\
$1 / 4$ & + & + & + & + & + & + & + & + & + & + & + & + & + & + & + \\
\hline
\end{tabular}



(Mus musculus) Sebagai Produk Imunoglobulin (IgM)

Tabel 3. Titer Imunoglobulin M (IgM) pada mencit setelah pemberian sel darah merah domba (SDMD) $2 \%$ yang diinduksi dengan ekstrak etanol buah Mangga (Mangifera indica L)

\begin{tabular}{ccccccc}
\hline \multirow{2}{*}{ Replikasi } & \multicolumn{6}{c}{ Titer Imunoglobulin M (IgM) } \\
\cline { 2 - 7 } & $\mathbf{2 \%}$ & $\mathbf{4} \%$ & $\mathbf{6} \%$ & $\mathbf{8} \%$ & $\mathbf{1 0 \%}$ & Kontrol (-) \\
\hline 1 & $1 / 8$ & $1 / 4$ & $1 / 32$ & $1 / 512$ & $1 / 8$ & $1 / 8$ \\
2 & $1 / 8$ & $1 / 4$ & $1 / 16$ & $1 / 128$ & $1 / 8$ & $1 / 8$ \\
3 & $1 / 8$ & - & $1 / 18$ & - & - & $1 / 8$ \\
\hline
\end{tabular}

\section{PEMBAHASAN}

Penelitian ini bertujuan untuk mengetahui adanya antibodi yang terbentuk didalam tubuh mencit setelah pemberian ekstrak etanol buah mangga. Antibodi adalah globulin protein (imunoglobulin) yang akan bereaksi secara spesifik dengan antigen yang menstimulasi produksi dari respon imun.

Pada penelitian ini, digunakan antigen berupa sel darah merah domba (SDMD) yang bersifat tidak larut, sehingga metode yang digunakan adalah metode hemaglutinasi (aglutinasi menggunakan sel darah merah oleh antibodi).

\section{Pengamatan aktivitas}

imunoglobulin dilakukan dengan melihat aglutinasi yang terjadi dan dihitung sebagai titer antibodi yaitu pengenceran tertinggi dari serum darah mencit yang masih menunjukkan reaksi aglutinasi positif pada sumur mikrotitrasi. Hasil akhir dari uji hemaglutinasi dapat ditentukan dengan melihat pola pengendapan sel darah merah pada dasar well plate. Apabila sel darah merah membentuk titik berwarna merah pada pusat sumur dan terlihat bening uji dinyatakan negatif. Sel yang teraglutinasi akan menyebar pada cairan di dalam sumuran.

Dari hasil pengamatan titer aglutinasi, menunjukan peningkatan aktivitas imunoglobulin $\mathrm{M}(\lg \mathrm{M})$. Hal ini dapat dilihat pada kelompok perlakuan pemberian ekstrak etanol buah mangga dengan konsentrasi $6 \%$ dan $8 \% \mathrm{~b} / \mathrm{v}$ titer imunoglobulin masingmasing sebesar 1/32, dan 1/512 sedangkan pada ekstrak etanol buah mangga konsentrasi $2 \%$ dan $10 \%$ sama dengan kelompok perlakuan kontrol, rata-rata titer imunoglobulinnya hanya 1/8 dan pada 
Identifikasi Aktivitas Ekstrak Etanolik Buah Mangga (Mangifera indica L.) Pada mencit jantan (Mus musculus) Sebagai Produk Imunoglobulin (IgM)

konsentrasi $4 \%$ mengalami penurunan

aktivitas imunoglobulin M yaitu $1 / 4$. Hal ini diduga disebabkan karena respon imun sangat ditentukan oleh kesetimbangan jumlah antigen dan antibodi. Apabila jumlah dari antigen atau antibodi tidak seimbang (salah satu diantaranya berlebihan) maka pembentukan antibodi akan terganggu.

Berdasarkan pengamatan pengenceran tertinggi dari serum darah mencit yang masih dapat mengaglutinasi sel darah merah domba $2 \%$ memperlihatkan bahwa pemberian ekstrak etanol buah mangga memberikan efek terhadap peningkatan aktivitas Imunoglobulin M (IgM).

\section{KESIMPULAN}

Berdasarkan hasil penelitian bahwa ekstrak etanol buah mangga (Mangifera indica L) dapat meningkatkan aktivitas Imunoglobulin M (IgM) pada mencit jantan (Mus musculus) dengan konsentrasi minimal ekstrak etanolik buah mangga adalah $6 \%$, dan $8 \%$.

\section{DAFTAR PUSTAKA}

1. Puspaningtyas DE. The Miracle of Fruits. Jakarta : Agromedia Pustaka, 2013.

2. Percivel dkk. Neoplastic transformation of BALB/3T3 cells and cell cycle of HL-60 cells are inhibited by mango (Mangifera indica L.) juice and mango juice extracts. J Nutr 2006;136(5):13001304

3. Effendi $\mathrm{N}$, Widiastuti $\mathrm{H}$. Identifikasi Aktivitas Imunoglobulin M (IGM) ekstrak etanolik daun Ceplukan (Physalis minima linn.) pada mencit (Mus muscullus). Volume VII No. 2/2014. 